\title{
Pemetaan Rawan Longsor Daerah Palu Dengan Metode Weight Overlay
}

\author{
Intan Pratiwi ${ }^{1}$, Muhammad Adli Ito ${ }^{1}$, Muthazhar Al Rasyid Harahap ${ }^{1 *}$, Frederic Steven ${ }^{2}$ \\ ${ }^{1}$ Jurusan Teknik Geofisika, Fakultas Teknik, Universitas Lampung, Jl. Prof. Dr. Ir. Sumantri Brojonegoro, Bandar \\ Lampung, Lampung 35141 \\ ${ }^{2}$ Program Studi Geofisika, Fakultas Matematika dan IImu Pengetahuan Alam, Universitas Indonesia, Jl. Margonda Raya, Pondok \\ Cina, Kecamatan Beji, Kota Depok, Jawa Barat 16424
}

Dikirim:
27 September 2020
Direvisi:
5 November 2021
Diterima:
15 November 2021
*Email Korespondensi:
alrasyidhrp@gmail.com
(c) †) (2)

Abstrak: Topografi yang berbukit dengan tingkat kemiringan yang cukup tinggi menjadi salah satu faktor penting yang mempengaruhi terjadinya longsor. Hal ini didukung dengan kondisi alam Kota Palu yang dominan dengan daerah perbukitan yang cukup terjal juga sangat berpengaruh terhadap terjadinya bencana longsor. Penelitian ini dilakukan dengan tujuan untuk memanfaatkan SIG dalam pemetaan tingkat kerawanan terjadinya bencana longsor di Kota Palu, Sulawesi Tengah. Hasil penelitian menunjukkan curah hujan pada wilayah penelitian didominasi oleh intensitas yang sedang hingga tinggi berada pada kisaran di bawah 700 hingga di atas 2500. Jenis tanah yang mendominasi yaitu jenis batuan kapur dan metamorf Dengan didominasi oleh batuan kapur dan metamorf. Kemudian jenis batuan didominasi oleh batuan berkapur dan metamorf, batuan sedimen serta batuan vulkanik. Berdasarkan peta kemiringan lereng Kota Palu, dibagi 4 klasifikasi kemiringan lereng berdasarkan kemiringannya Sangat Rendah, Rendah, Sedang, dan Tinggi. Hasil dari pemanfaatan SIG ini kita dapat mengetahui bahwa kabupaten Palu memiliki potensi bencana longsor yang cukup tinggi karena Kondisi tanah di Kota Palu yang cenderung tidak memiliki sumber serapan yang baik, sehingga air yang masuk ke dalam tanah tidak dapat menahan dan mengakibatkan erosi pada lapisan tanah yang dilewatinya.

Kata kunci: batuan, hujan, lereng, longsor, palu, topografi

\begin{abstract}
Very steep terrain with a high slope is one of the important factors affecting landslides. This is supported by the dominant nature of the city of Palu with its relatively steep hill country which also greatly influences landslides. This study aims to using GIS in mapping the level of vulnerability to landslides in Palu City, Central Sulawesi. The results showed that rainfall in the study area was dominated by intensities in the range of below 700 to above 2500. The type of soil that dominated was limestone and metamorphic rocks dominated by limestone and metamorphic rocks. The next type of rock is dominated by rocks and metamorphs, sedimentary rocks, volcanic rocks. Based on the slope map of the city of Palu, divided into 4 slope classifications based on their slope Very Low, Low, Medium, and High they do not have a good source of absorption, so water entering the ground cannot withstand the erosion of the soil they pass through.
\end{abstract}

Keywords: landslide, palu, rainfall, rock, slope, topography

\section{PENDAHULUAN}

Bencana tanah longsor telah mengakibatkan lebih banyak kerugian dibandingkan dengan bencana lain. Setiap tahun, kasus bencana tanah longsor semakin meningkat terutama saat memasuki musim hujan terutama di daerah-daerah perbukitan terjal. Berdasarkan data, tercatat kejadian bencana tanah longsor terjadi pada 809 lokasi di seluruh wilayah Indonesia yang memakan korban jiwa 2484 orang meninggal dunia (BNPB, 2012).

Potensi terjadinya bencana alam pada dasarnya merupakan suatu gambaran fenomena alam yang khas terutama untuk wilayah Indonesia yang secara geografis memiliki bentang alam yang kompleks. Indonesia berada pada lokasi yang strategis yang diapit oleh tiga lempeng besar dunia, yaitu lempeng Indo-Australia, Eurasia dan Pasifik. Proses geodinamika yang intensif dan kompleks membentuk relief permukaan bumi yang khas dan bervariasi, mulai dari sepanjang pantai dengan potensi tsunami, hingga wilayah perbukitan dengan lereng yang curam sehingga potensi longsor di daerah Bandung Barat semakin tinggi (Hardianto dkk., 2020).

Tanah longsor adalah gerakan tanah yang berkaitan dengan hal alami seperti struktur geologi, tanah, drainase, hujan, lereng, serta faktor non alami seperti penggunaan lahan dan infrastruktur (Barus 1999). Rahman dkk., (2014) menyampaikan bahwa selain iklim dan geotektonik, faktor manusia yaitu aktivitas manusia di atas lahan yang membebani lereng juga berkontribusi dalam terjadinya tanah longsor. Tanah longsor atau gerakan tanah merupakan peristiwa yang terjadi akibat pergerakan massa batuan ataupun tanah. Tanah longsor sering terjadi di Indonesia dan mengakibatkan kerugian baik material ataupun non material. Bencana tanah longsor dapat dipengaruhi oleh berbagai faktor, baik secara alami maupun akibat kondisi sosial. Selain faktor alam, ternyata faktor sosial yang terjadi di masyarakat juga perlu dikaji dalam mengidentifikasi bencana alam. Secara geologis tanah longsor adalah suatu peristiwa geologi dimana terjadi pergerakan tanah seperti jatuhnya bebatuan atau gumpalan besar tanah 
(Nandi, 2007). Proses terjadinya tanah longsor dapat di jelaskan sebagai berikut, air yang meresap ke dalam tanah akan menambah bobot tanah. Jika air tersebut menembus sampai tanah kedap air yang berperan sebagai bidang gelincir, maka tanah menjadi licin dan tanah pelapukan di atasnya akan bergerak mengikuti lereng dan luar lereng.

(Susilo, 2008) mengemukakan bahwa longsor dapat terjadi dengan terpenuhinya syarat tertentu. Syarat tersebut adalah kondisi lereng yang curam, adanya lapisan tanah yang lunak dan kedap air sebagai bidang luncur, dan terdapat kandungan air yang cukup dalam tanah. Gerak tanah terjadi apabila terdapat keadaan ketidakseimbangan yang mengakibatkan bergeraknya sebagian dari lereng mengikuti gaya tarik bumi dan pada akhirnya terjadi longsor. Daerah yang membentuk lahan miring seperti di perbukitan dan daerah pegunungan sangat rawan akan terjadinya gerakan tanah. Suatu lereng dengan kemiringan $>20^{\circ}$ memiliki potensi longsor. Namun hal ini juga bergantung pada kondisi geologi lereng tersebut (Khadiyanto, 2008).

Biasanya longsoran terjadi akibat terbentuknya zona penjenuhan pada lapisan yang berada di dekat permukaan tanah (Wang dkk., 2017; Zakaria, 2010). Terbentuk zona penjenuhan ini akibat turunnya hujan dengan waktu yang relatif lama serta memiliki intensitas sedang hingga tinggi. Bencana longsor ini sangat menghancurkan bahkan menimbulkan korban jiwa. Oleh karena itu, upaya mitigasi sangat diperlukan dalam menghadapi terjadinya bencana alam terutama bencana longsor sehingga dampak yang timbul dapat dikurangi. Tidak adanya sistem peringatan dini yang dapat menyelamatkan masyarakat dan lingkungan serta minimnya pemahaman tentang lingkungan tempat mereka tinggal, menjadi penyebab banyaknya jatuh korban pada setiap bencana longsor (Rahman, 2014).
Pemetaan Risiko Bencana merupakan suatu kegiatan pembuatan peta dengan merepresentasikan dampak negatif yang dapat timbul pada suatu wilayah (Kurniawan, 2010). Penerapan teknologi informasi spasial berbasis SIG dapat membantu upaya mitigasi dengan melakukan identifikasi dan pengkajian masalah yang timbul akibat bencana longsor. Upaya mitigasi dapat dilakukan dengan membuat model SIG, dengan mengkorelasikan beberapa parameter sehingga diperoleh kawasan yang rentan terhadap bahaya bencana tanah longsor (Matondang dkk., 2013; Yasien, 2021). Tujuan dalam penelitian ini adalah untuk memetakan tingkat kerawanan bencana tanah longsor di Palu dengan memanfaatkan informasi spasial berbasis Sistem Informasi Geografis.

\section{BAHAN DAN METODE PENELITIAN}

Penelitian mengenai pemetaan daerah rawan bencana longsor ini dilakukan di Kota Palu, Sulawesi Tengah (Gambar 1). Lokasi penelitian berada pada posisi koordinat geografi 0 의 $\mathrm{LS}$ sampai -056'LS dan 199\%45'BT sampai 1211'BT, sehingga tepat berada di garis khatulistiwa dengan ketinggian di antara 0-700m di atas permukaan laut. Wilayah Kota Palu dicirikan oleh bentuk utama berupa lembah dimana pusat Kota terletak di bagian tengah dari lembah tersebut. Letak ini pula yang berpengaruh terhadap sebaran populasi yang relatif memusat di bagian tengah lembah. Orientasi lembah ini mengikuti arah utama jalur pegunungan di kedua sisinya, yaitu berarah relatif utara-selatan. Secara geologis, orientasi fisiografi ini berhubungan dengan proses struktur yang terjadi serta jenis batuan yang menyusun Kota Palu, dimana sisi kiri dan kanan Kota Palu merupakan jalur patahan utama, yaitu patahan Palu-Koro serta wilayahnya disusun oleh batuan yang lebih keras dibanding material penyusun bagian lembah.

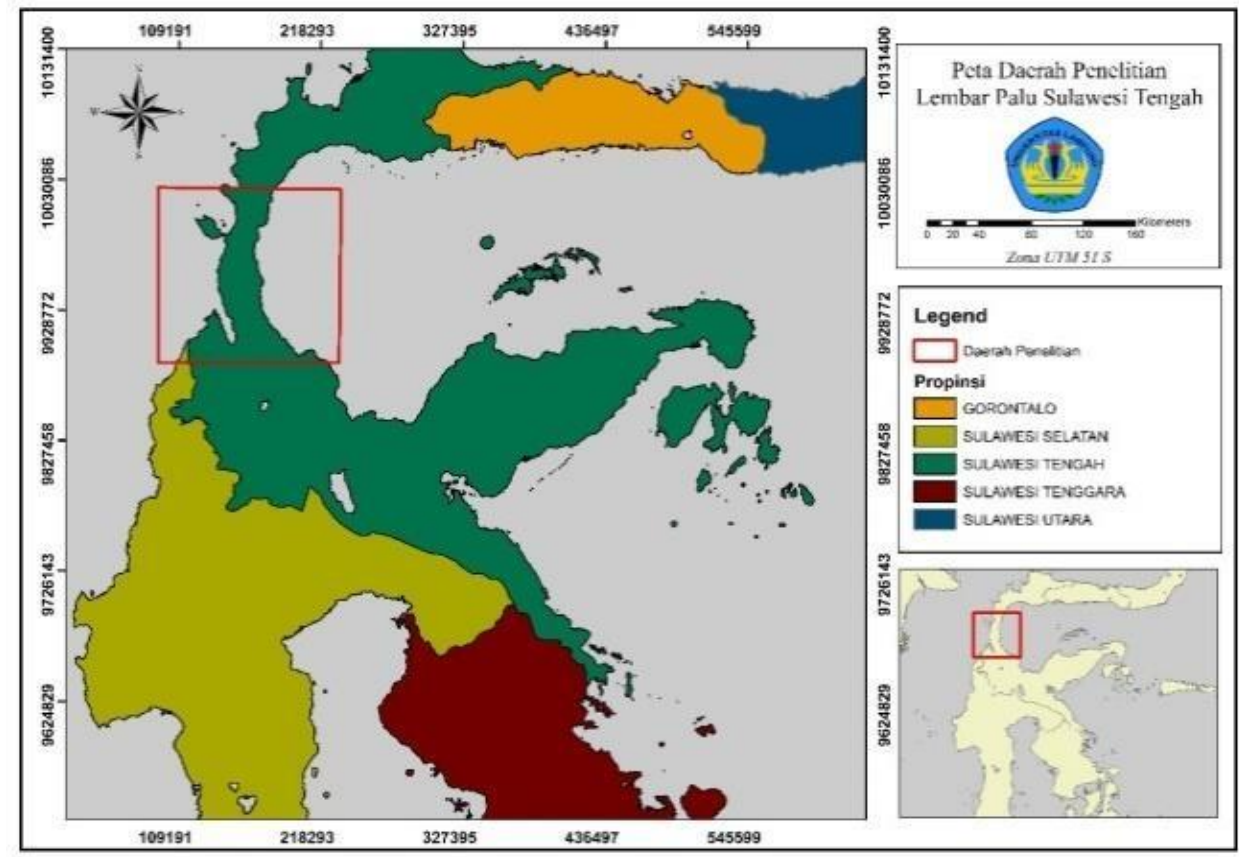

Gambar 1. Peta Lokasi Penelitian 
Bahan dan alat dalam penelitian ini adalah data curah hujan Kota Palu, data DEM atau model elevasi digital atau Digital Elevation Model (DEM) merupakan salah satu data dasar yang paling esensial dalam penelitian ini, selanjutnya yaitu data SRTM, data SRTM merupakan salah satu terobosan baru dalam teknologi pemetaan digital bumi (dengan resolusi spasial hingga 30 meter dan vertical error kurang dari 16 meter) dan mampu menyajikan data elevasi berkualitas tinggi dalam cakupan yang luas di daerah tropis dan bagian dunia lainnya, selanjutnya data yang digunakan yaitu peta jenis tanah, peta struktur geologi, peta tutupan lahan, peta kemiringan lereng, peta infrastruktur, peta jenis tanah data-data lainnya. Data-data ini kemudian diinput dalam software SIG.

Proses input data dilakukan secara digital melalui perangkat komputer dengan software ArcGIS 10.3. Analisis kerawanan tanah longsor dilakukan dengan melakukan skoring pada kategori yang digunakan (Indrasmono, 2013), kemudian setelah kategori selesai dilakukan pembobotan pada setiap kategori dengan menggunakan teknik Pembobotan yang digunakan yaitu pembobotan KemenPU, pembobotan tes 1 , dan pembobotan tes 2 seperti yang ditunjukkan pada Tabel 1 .

Tabel 1. Model skor dan pembobotan untuk analisis geospasial potensi longsor dengan teknik Index/Weighted Overlay.

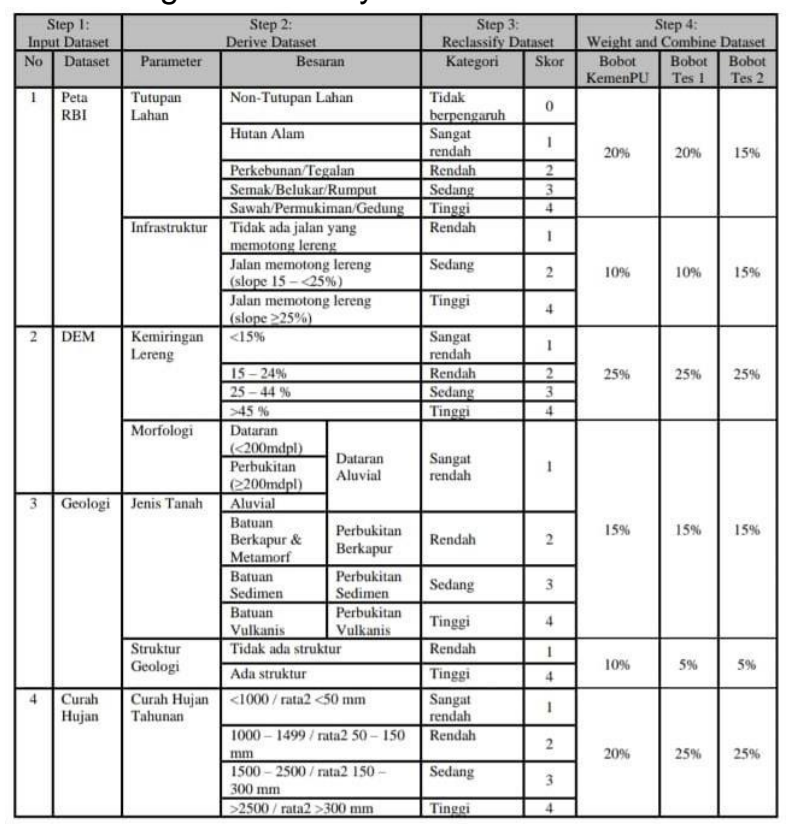

Berbagai masalah terkait dengan bencana tanah longsor di Kota Palu yang melatar belakangi penelitian yang dilakukan kelompok peneliti. Tindak lanjut dari permasalahan ini yaitu mencari solusi dan langkah tepat untuk mengatasi dan mengurangi dampak terjadinya tanah longsor. Salah satu langkah yang dapat dilakukan untuk mengurangi dampak tanah longsor adalah dengan mengenali karakteristik daerah rawan terjadinya longsor tersebut, yang mana untuk mengenali karakteritistik daerah terjadinya bencana tanah longsor maka diperlukan sebuah pemetaan daerah rawan bencana tanah longsor.

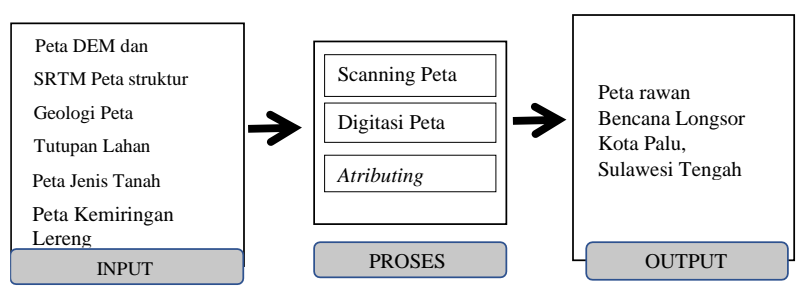

Gambar 2. Diagram Alir Penelitian Pemanfaatan Informasi Spasial Berbasis SIG untuk Pemetaan Tingkat Kerawanan Longsor di Kota Palu, Sulawesi Tengah

\section{HASIL DAN PEMBAHASAN}

\subsection{Faktor-faktor yang Mempengaruhi Longsor di Kota Palu}

Aspek hidrologi sangat diperlukan dalam pengendalian dan pengaturan tata air di suatu wilayah. Berdasarkan hasil penelitian diketahui bahwa pada daerah Kota Palu memiliki curah hujan yang cukup rendah. Kondisi tanah di Kota Palu yang cenderung tidak memiliki sumber serapan yang baik, sehingga air yang masuk ke dalam tanah tidak dapat menahan dan mengakibatkan erosi pada lapisan tanah yang dilewatinya. Topografi yang berbukit dengan tingkat kemiringan yang cukup tinggi menjadi salah satu faktor penting yang mempengaruhi terjadinya longsor. Hal ini didukung dengan kondisi alam Kota Palu yang dominan dengan daerah perbukitan yang cukup terjal juga sangat berpengaruh terhadap terjadinya bencana longsor. Kondisi alam pada Kota Palu menyebabkan potensi bencana di Kota Palu cukup tinggi, terutama bencana longsor atau pergerakan tanah.

\subsection{Curah Hujan}

Berdasarkan peta curah hujan Kota Palu pada Gambar 3, curah hujan di lokasi penelitian termasuk cukup rendah. Tingkat intensitas hujan dan distribusi curah hujan di kawasan penelitian, menjadi salah satu parameter penting dalam menentukan wilayah yang memiliki tingkat rawan longsor. Berdasarkan peta curah hujan Kota Palu, dibagi 3 klasifikasi curah hujan berdasarkan intensitasnya, yaitu Rendah, Sedang, dan Tinggi. Berdasarkan peta curah hujan Kota Palu, Kecamatan Balaroa, Kecamatan Bayu, Kecamatan Bayaoge, Kecamatan Besusu Barat, Kecamatan Besusu Tengah, Kecamatan Besusu Timur, Kecamatan Birobuli Selatan, Kecamatan Birobuli Utara, Kecamatan Buluri, Kecamatan Donggala Kodi, Kecamatan Duyu, Kecamatan Kabonena, Kecamatan Kamonji, Kecamatan Kayumalue Pajeko, Kecamatan Lambara, Kecamatan Lere, 
Kecamatan Lolu Selatan, Kecamatan Lolu Utara, Kecamatan Nunu, Kecamatan Palupi, Kecamatan Panau, Kecamatan Pengawu, Kecamatan Petobo, Kecamatan Silae, Kecamatan Sirandini, Kecamatan Taipa, Kecamatan Talise, Kecamatan Tanamodindi, Kecamatan Tatura Selatan, Kecamatan Tatura Utara, Kecamatan Tavanjuka, Kecamatan Tipo, Kecamatan Ujuna, Kecamatan Watusampu merupakan daerah yang memiliki intensitas hujan yang rendah. Kecamatan Baiya, Kecamatan Kayumaluengapa, Kecamatan Layana Indah, Kecamatan Mamboro, Kecamatan Mamboro Barat, Kecamatan Pantoloan, Kecamatan Poboya, Kecamatan Tondo merupakan daerah yang memiliki intensitas hujan yang sedang. Kecamatan Lasoani, Kecamatan Kawatuna, Kecamatan Pantoloan Boya merupakan daerah yang memiliki intensitas hujan yang tinggi.

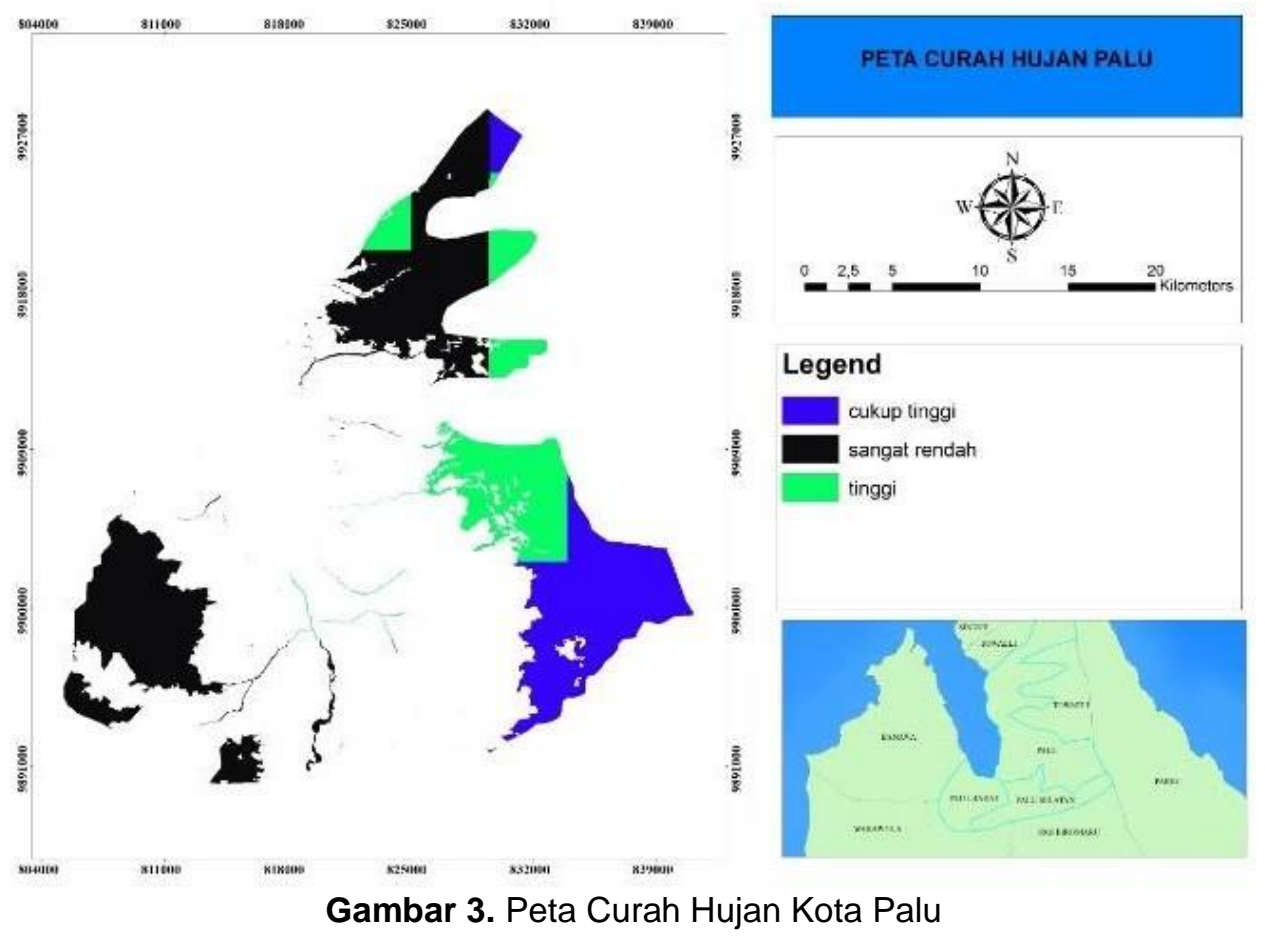

\subsection{Jenis Tanah}

Sifat setiap batuan berbeda karena dipengaruhi oleh asal terbentuknya batuan tersebut. Umumnya, batuan dipengaruhi oleh tekstur, struktur, kekar, kandungan mineral, cuaca, dan sedimentasi. Berdasarkan peta jenis tanah Kota Palu pada Gambar 4, wilayah Kota Palu didominasi oleh batuan kapur dan metamorf, hal ini dipengaruhi oleh adanya perbukitan yang mengandung batuan kapur dan metamorf. Dengan didominasi oleh batuan kapur dan metamorf hal ini menunjukkan bahwa kemungkinan besar batuan sedimen yang berada pada Kota Palu berasal dari hasil erosi dan pelapukan batuan vulkanik pada wilayah tersebut. Berdasarkan peta jenis tanah Kota Palu, dibagi 3 klasifikasi jenis tanah berdasarkan batuannya Batuan Berkapur dan Metamorf, Batuan Sedimen, Batuan Vulkanik. Berdasarkan peta jenis tanah Kota Palu, Kecamatan Baiya, Kecamatan Kabonena, Kecamatan Kayumalue Pajeko, Kecamatan Panau, Kecamatan Pantoloan, Kecamatan Silae, Kecamatan Taipa merupakan daerah yang memiliki jenis tanah Batuan Berkapur dan Metamorf. Kecamatan Balaroa, Kecamatan Bayu, Kecamatan Bayaoge, Kecamatan Besusu Barat, Kecamatan Besusu Tengah, Kecamatan Besusu Timur, Kecamatan Birobuli Selatan, Kecamatan Birobuli Utara, Kecamatan Donggala Kodi, Kecamatan Kamonji, Kecamatan Kawatuna, Kecamatan Kayumaluengapa, Kecamatan Lambara, Kecamatan Layana Indah, Kecamatan Lasoani, Kecamatan Lere, Kecamatan Lolu Selatan, Kecamatan Lolu Utara, Kecamatan Mamboro, Kecamatan Mamboro Barat, Kecamatan Nunu, Kecamatan Pantoloan Boya, Kecamatan Petobo, Kecamatan Poboya, Kecamatan Sirandini, Kecamatan Talise, Kecamatan Tanamodindi, Kecamatan Tatura Selatan, Kecamatan Tatura Utara, Kecamatan Tavanjuka, Kecamatan Tondo, Kecamatan Ujuna merupakan daerah yang memiliki jenis tanah Batuan Sedimen. Kecamatan Buluri, Kecamatan Duyu, Kecamatan Palupi, Kecamatan Pengawu, Kecamatan Tipo Kecamatan Watusampu merupakan daerah yang memiliki jenis tanah Batuan Vulkanis. 


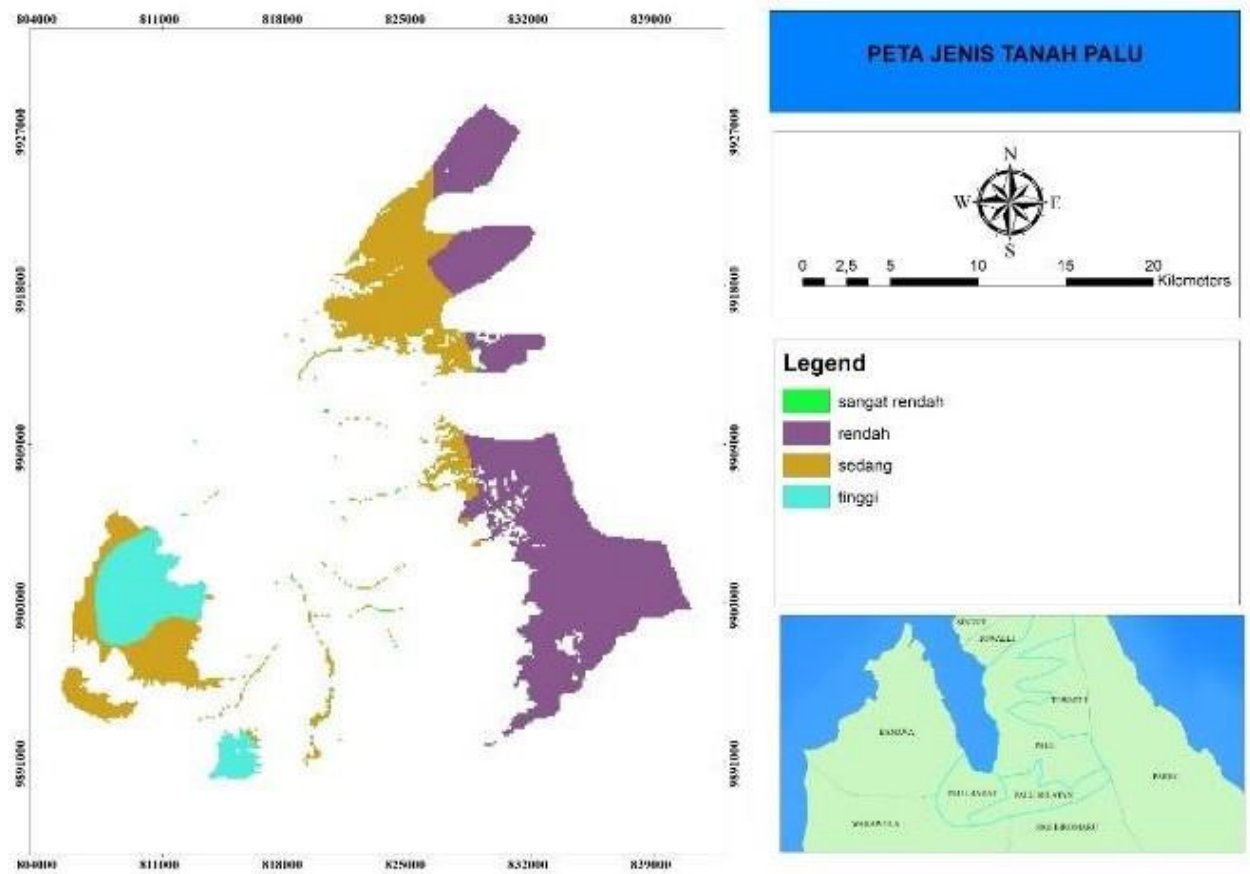

Gambar 4. Peta Jenis Tanah Kota Palu

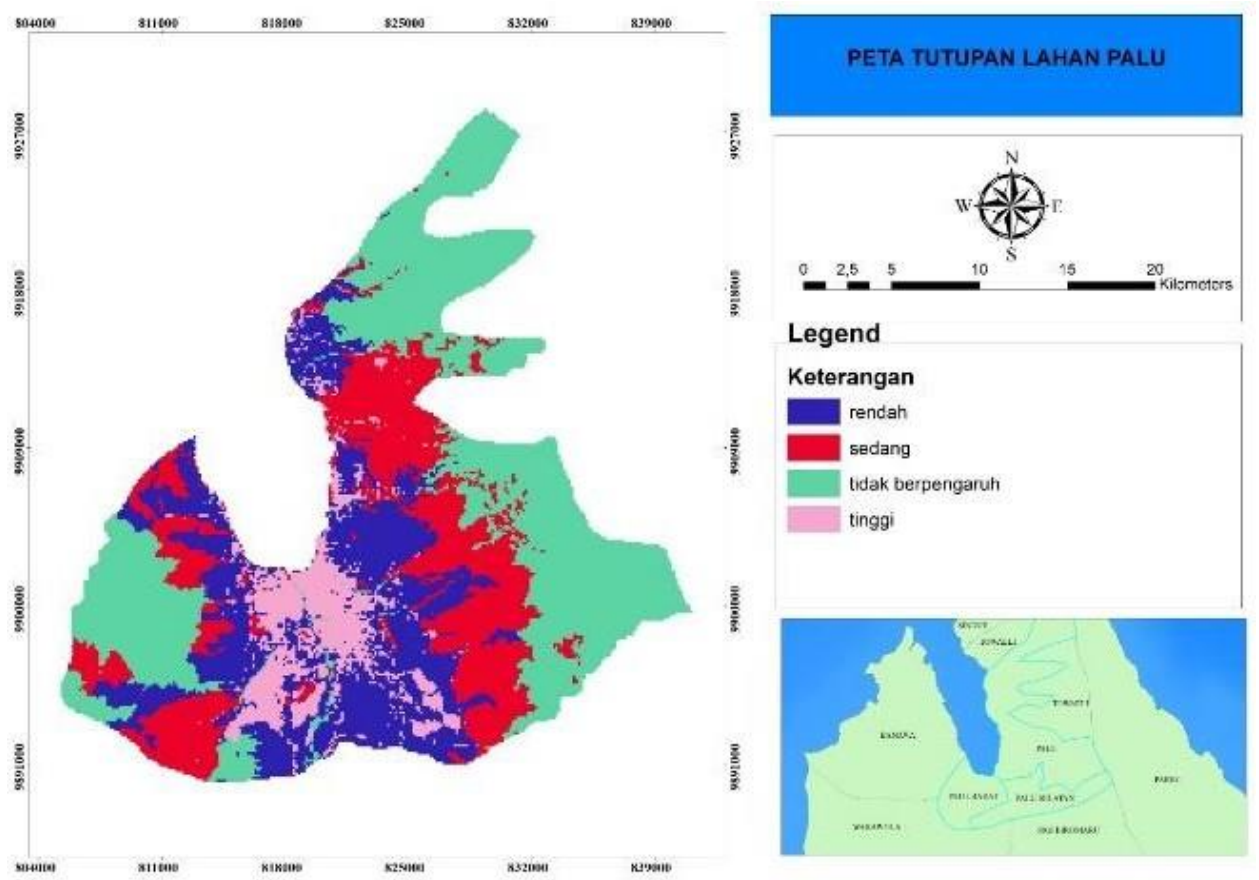

Gambar 5. Peta Penggunaan Lahan Kota Palu

\subsection{Penggunaan Lahan}

Berdasarkan peta penggunaan lahan Kota Palu pada Gambar 5 dapat dilihat bahwa penutupan lahan pada peta ini memiliki kontribusi yang berbeda-beda tergantung pada sifat dan kondisi penutupan lahan. Penutupan serta lokasi penutupan lahan itu berada adalah hal-hal yang berpengaruh dalam penentuan kerawanan wilayah yang kaitannya kecenderungan suatu wilayah memiliki daerah resapan air yang baik atau tidak. Berdasarkan peta penggunaan lahan Kota Palu, penggunaan lahan di lokasi penelitian didominasi oleh Sawah/Permukiman/Gedung. Berdasarkan peta penggunaan lahan Kota Palu, dibagi 4 klasifikasi penggunaan lahan berdasarkan penutupannya yaitu Non-Tutupan Lahan, Perkebunan/Tegalan, Semak/Belukar/Rumput, Sawah/Permukiman/Gedung.

\subsection{Kemiringan Lereng}

Berdasarkan peta kemiringan lereng Kota Palu pada Gambar 6, kemiringan lereng di lokasi penelitian termasuk cukup tinggi. Tingkat kemiringan lereng di kawasan penelitian, juga menjadi salah satu parameter penting dalam menentukan wilayah yang memiliki tingkat rawan longsor. Berdasarkan peta kemiringan lereng Kota Palu, dibagi 4 klasifikasi kemiringan lereng 
berdasarkan kemiringannya Sangat Rendah, Rendah, Sedang, dan Tinggi. Dimana Sangat Rendah memiliki kemiringan di bawah $15^{\circ}$, Rendah memiliki kemiringan $15^{\circ}-24^{\circ}$, Sedang memiliki kemiringan $24^{\circ}-44^{\circ}$ dan Tinggi memiliki kemiringan di atas $45^{\circ}$. Berdasarkan peta kemiringan lereng Kota Palu, Kecamatan Baiya, Kecamatan Lambara, Kecamatan Kayumaluengapa, Kecamatan Kayumalue Pajeko merupakan daerah yang memiliki kemiringan lereng yang Sangat Rendah. Kecamatan Pantoloan, Kecamatan Panau merupakan daerah yang memiliki kemiringan lereng yang Rendah.
Kecamatan Balaroa, Kecamatan Bayu, Kecamatan Bayaoge, Kecamatan Besusu Barat, Kecamatan Besusu Tengah, Kecamatan Besusu Timur, Kecamatan Birobuli Selatan, Kecamatan Birobuli Utara, Kecamatan Donggala Kodi, Kecamatan Duyu, Kecamatan Kamonji, Kecamatan Kawatuna, Kecamatan Lasoani, Kecamatan Layana Indah, Kecamatan Lere, Kecamatan Lolu Selatan, Kecamatan Lolu Utara, Kecamatan Mamboro, Kecamatan Mamboro Barat, Kecamatan Nunu, Kecamatan Poboya, Kecamatan Palupi, Kecamatan Pantoloan Boya, Kecamatan Pengawu,

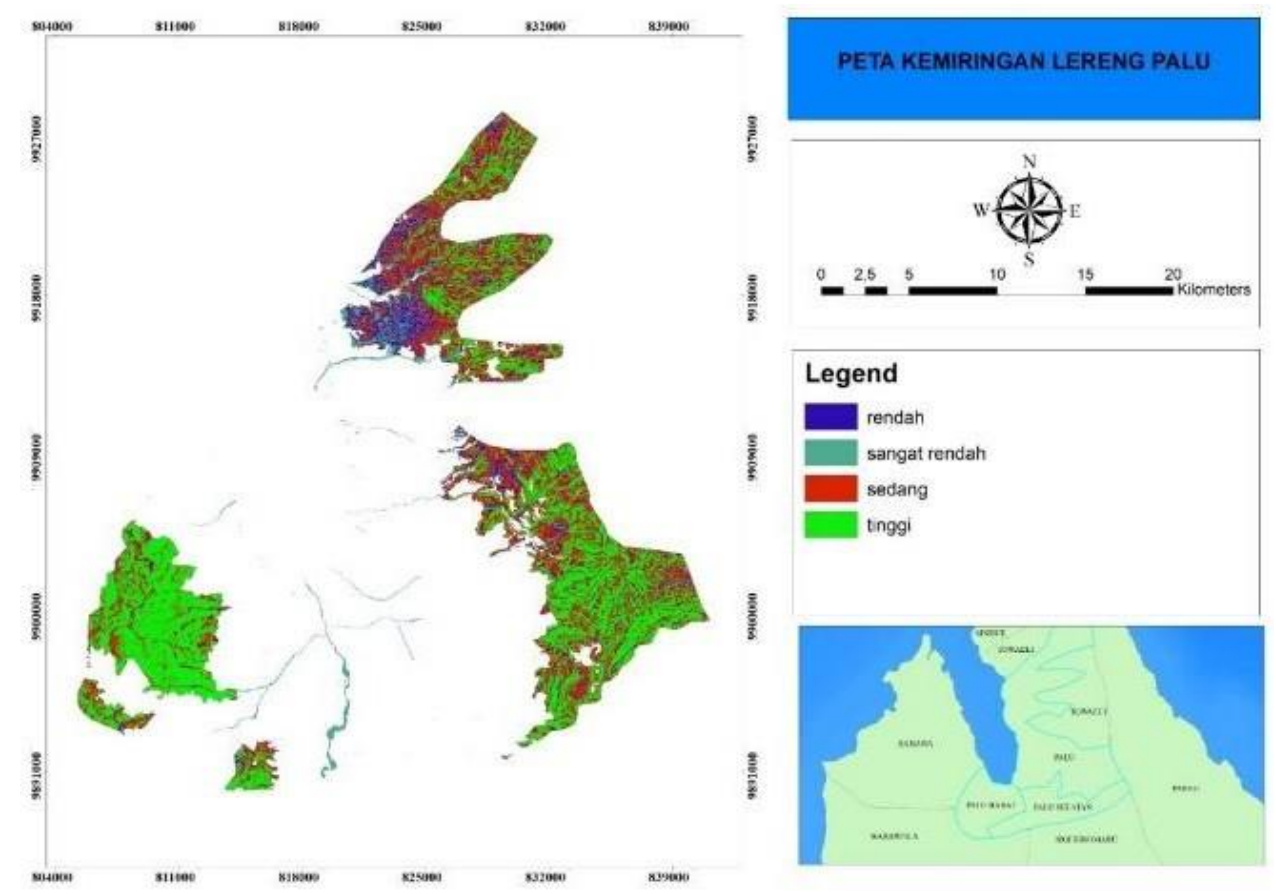

Gambar 6. Peta Kemiringan Lereng Kota Palu

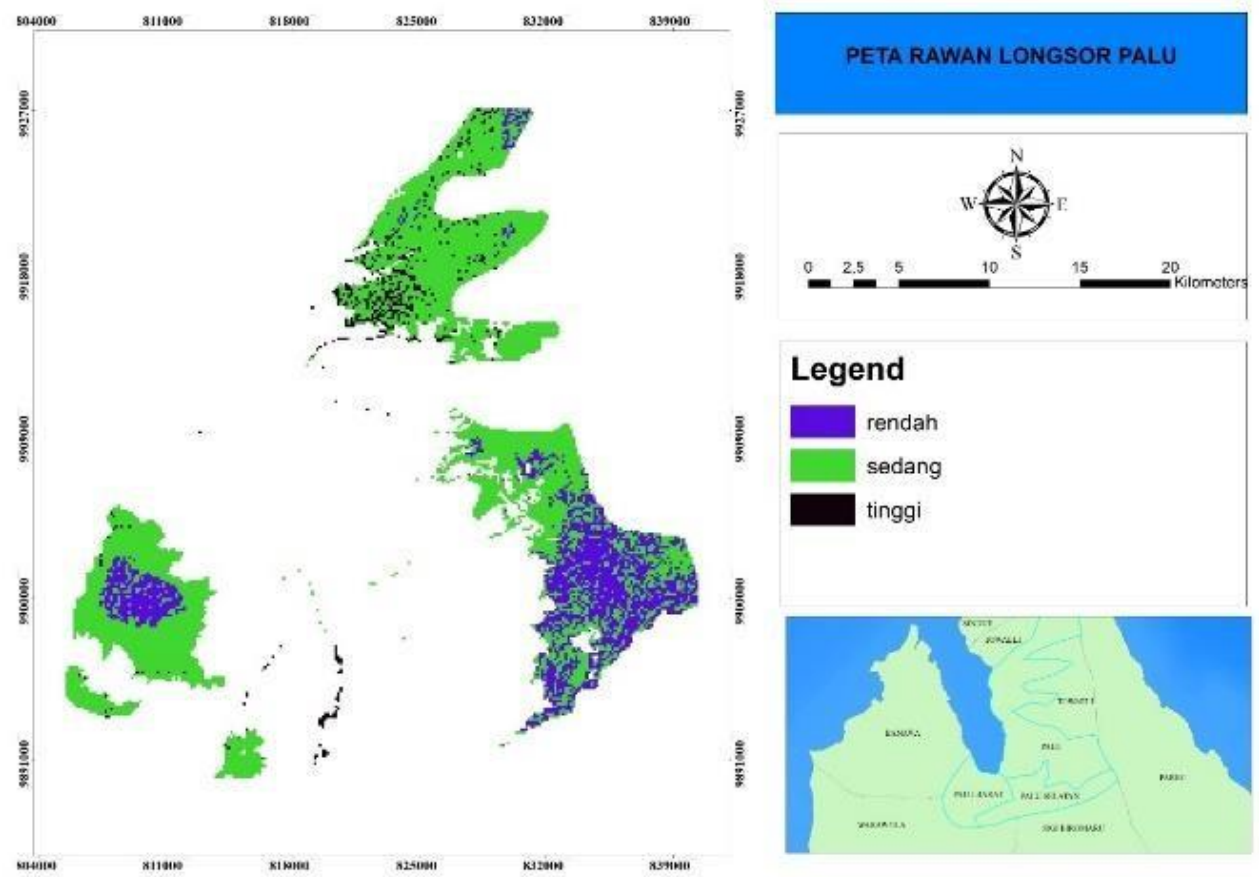

Gambar 7. Peta Rawan Longsor Kota Palu 
Kecamatan Petobo, Kecamatan Sirandini, Kecamatan Taipa, Kecamatan Talise, Kecamatan Tanamodindi, Kecamatan Tatura Selatan, Kecamatan Tatura Utara, Kecamatan Tavanjuka, Kecamatan Tondo, Kecamatan Ujuna merupakan daerah yang memiliki kemiringan lereng yang Sedang. Kecamatan Buluri, Kecamatan Kabonena, Kecamatan Silae, Kecamatan Tipo, Kecamatan Watusampu merupakan daerah yang memiliki kemiringan lereng yang Tinggi.

\section{KESIMPULAN}

Berdasarkan penelitian yang sudah dilakukan maka dapat disimpulkan bahwa terdapat lima faktor utama yang mempengaruhi tingkat kerawanan longsor pada wilayah Kabupaten Palu diantaranya yaitu jenis tanah, curah hujan, jenis batuan dan penggunaan lahan. Curah hujan pada wilayah penelitian didominasi oleh intensitas yang sedang hingga tinggi berada pada kisaran di bawah 700 hingga diatas 2500. Jenis tanah yang mendominasi yaitu jenis batuan kapur dan metamorf Dengan didominasi oleh batuan kapur dan metamorf hal ini menunjukkan bahwa kemungkinan besar batuan sedimen yang berada pada Kota Palu berasal dari hasil erosi dan pelapukan batuan vulkanik pada wilayah tersebut. Kemudian jenis batuan didominasi oleh batuan berkapur dan metamorf, batuan sedimen, batuan vulkanik.

Berdasarkan peta kemiringan lereng Kota Palu, dibagi 4 klasifikasi kemiringan lereng berdasarkan kemiringannya Sangat Rendah, Rendah, Sedang, dan Tinggi. Dimana Sangat Rendah memiliki kemiringan di bawah $15^{\circ}$, Rendah memiliki kemiringan $15^{\circ}-24^{\circ}$, Sedang memiliki kemiringan $24^{\circ}-44^{\circ}$, dan Tinggi memiliki kemiringan di atas $45^{\circ}$. Berdasarkan peta penggunaan lahan Kota Palu, penggunaan lahan di lokasi penelitian didominasi oleh Sawah/Permukiman/Gedung. Berdasarkan peta penggunaan lahan Kota Palu, dibagi 4 klasifikasi penggunaan lahan berdasarkan penutupannya yaitu Non-Tutupan Lahan, Perkebunan/Tegalan, Semak/Belukar/Rumput, Sawah/Permukiman/Gedung.

Hasil dari pemanfaatan SIG ini kita dapat mengetahui bahwa kabupaten Palu memiliki potensi bencana longsor yang cukup tinggi karena Kondisi tanah di Kota Palu yang cenderung tidak memiliki sumber serapan yang baik, sehingga air yang masuk ke dalam tanah tidak dapat menahan dan mengakibatkan erosi pada lapisan tanah yang dilewatinya. Topografi yang berbukit dengan tingkat kemiringan yang cukup tinggi menjadi salah satu faktor penting yang mempengaruhi terjadinya longsor. Hal ini didukung dengan kondisi alam Kota Palu yang dominan dengan daerah perbukitan yang cukup terjal juga sangat berpengaruh terhadap terjadinya bencana longsor.

\section{UCAPAN TERIMA KASIH}

Terima kasih kepada seluruh pihak terkait yang turut andil dalam melaksanakan penelitian ini.
Terima kasih kami ucapkan kepada Badan Informasi Geospasial atas data-data yang diperlukan dalam penelitian ini, serta seluruh pihak yang membantu dalam penulisan dan pengolahan data penelitian ini.

\section{DAFTAR PUSTAKA}

Barus, B. (1999). Landslide Hazard Mapping based on GIS Univariate Statistical Classification: Case Study of Ciawi- Puncak-Pacet Regions, West Java. Jurnal IImu Tanah dan Lingkungan, 2(1).

BNPB. (2012). Peraturan Kepala Badan Nasional Penanggulangan Bencana (BNPB) No. 02 Tahun 2012 tentang Pedoman Umum Pengkajian Risiko Bencana. Badan Nasional Penanggulangan Bencana (BNPB): Jakarta.

Hardianto, A., Winardi, D., Rusdiana, D. D., Putri, A. C. E., Ananda, F., Devitasari, Djarwoatmodjo, F. S., Yustika, F., \& Gustav, F. (2020). Pemanfaatan Informasi Spasial Berbasis SIG untuk Pemetaan Tingkat Kerawanan Longsor di Kabupaten Bandung Barat, Jawa Barat. Jurnal Geosains Dan Remote Sensing, 1(1), 23-31.

Indrasmono, G. P. (2013). Geographic Information System (GIS) Untuk Deteksi Daerah Rawan Longsor Studi Kasus di Kelurahan Karang Anyar Gunung Semarang. Jurnal GIS Deteksi Rawan Longsor.

Khadiyanto, P. (2008). Gerakan Tanah (Longsoran). Retrieved April 9, 2021,from http://parfikh.blogspot.com/2008/12/gerakan -tanah-longsoran.html

Kurniawan, A. T. (2010). Visualisasi Risiko Bencana di Atas Peta: Studi Kasus: Penyusunan Peta Risiko di Provinsi DI. Yogyakarta. Fakultas Teknik Geodesi Universitas Gadjah Mada. Yogyakarta.

Matondang, J. P., Kahar, S., \& Sasmito, B. (2013). Analisis Zonasi Daerah Rentan Banjir Dengan Pemanfaatan Sistem Informasi Geografis (Studi Kasus : Kota Kendal dan Sekitarnya). Jurnal Geodesi Undip, 2(2), 103113.

Nandi. (2007). Longsor. Bandung: FPIPS-UPI.

Rahman, M. W., Purwanto, M. Y. J., \& Suprihatin. (2014). Status Kualitas Air dan Upaya Konservasi Sumberdaya Lahan di DAS Citarum Hulu, Kabupaten Bandung. Jurnal Pengelolaan Sumberdaya Alam Dan Lingkungan, 4(1), 24-34.

Susilo, J. (2008). Pengembangan Model SIG Penentuan Kawasan Rawan Longsor Sebagai Masukan Rencana Tata Ruang; Studi Kasus: Kabupaten Tegal. Tesis, Universitas Diponegoro.

Wang, F., Xu, P., Wang, C., Wang, N., \& Jiang, N. (2017). Application of a GIS-Based Slope Unit Method for Landslide Susceptibility Mapping along the Longzi River, Southeastern Tibetan Plateau, China. ISPRS 
International Journal of Geo-Information, 6, Zakaria, Z. (2010). Model Starlet, suatu Usulan 172.

Yasien, N. F., Yustika, F., Permatasari, I. \& Sari, M. (2021). Aplikasi Geospasial Untuk Analisis Potensi Bahaya Longsor Menggunakan Metode Weighted Overlay (Studi Kasus Kabupaten Kudus, Jawa Tengah). Jurnal
Geosains Dan Remote Sensing, 2(1), 33-40 untuk Mitigasi Bencana Longsor dengan Pendekatan Genetika Wilayah (Studi Kasus: Longsoran Citatah, Padalarang, Jawa). Indonesian Journal on Geoscience, 5(2), 93112. 